\title{
Ecological correlates of dispersal success of Lessepsian fishes
}

\author{
F. Ben Rais Lasram ${ }^{*}{ }^{1,2}$, J. A. Tomasini ${ }^{1}$, F. Guilhaumon ${ }^{1}$, M. S. Romdhane ${ }^{2}$, \\ T. Do Chi ${ }^{1}$, D. Mouillot ${ }^{1}$ \\ ${ }^{1}$ Laboratoire Ecosystèmes Lagunaires, UMR CNRS-IFREMER-UM2 5119, Université Montpellier 2, cc 093, \\ place Eugène Bataillon, 34095 Montpellier Cedex 5, France \\ ${ }^{2}$ Laboratoire Ecosystèmes et Ressources Aquatiques, Institut National Agronomique de Tunisie, 43 avenue Charles Nicolle, \\ 1082 Tunis, Tunisie
}

\begin{abstract}
Despite the importance of Lessepsian invasion by migrant fish species from the Red Sea into the Mediterranean Sea via the Suez Canal, determinants of invasive success have been poorly investigated. In this study, we reconstructed the spatio-temporal dynamics of all Lessepsian fish species in the Mediterranean Sea and analysed the relationship between ecological variables and dispersal rate. We created a database on species occurrences based on historical data (1869 to 2005) and estimated the dispersal rate of each species. Overall, $30 \%$ of the Lessepsian species succeeded in colonizing the Mediterranean Sea. On average, the 43 Lessepsian species not included in the category 'absence of dispersal' disperse at a rate of $221 \pm 5.4 \mathrm{~km} \mathrm{yr}^{-1}$ (SE) on the northern side and $70 \mathrm{~km} \mathrm{yr}^{-1}\left(\mathrm{SE}=3 \mathrm{~km} \mathrm{yr}^{-1}\right)$ on the southern side. Among the ecological variables studied, climate match, the year of introduction and interactions of both factors were significantly correlated with dispersal success. According to our observations, subtropical species introduced before 1980 have an advantage in the dispersal process. The transition from the Levantine basin to the western basin is clearly associated with a deceleration in dispersal rate that is likely due to a thermal barrier. In addition, we showed that species with pelagic propagules (eggs) tend to disperse more on the northern side (in comparison to the southern side) than do species with benthic propagules. This pattern was related to the counterclockwise surface circulation in the Levantine basin. We concluded that crossing the Suez Canal does not guarantee successful invasion and widespread dispersal of fish populations and that species ecology is a key determinant for dispersal success.
\end{abstract}

KEY WORDS: Lessepsian fish · Climate match · Exotic $\cdot$ Dispersal $\cdot$ Suez Canal $\cdot$ Mediterranean Sea Propagules · Year of introduction

\section{INTRODUCTION}

Dispersal of exotic species has produced marked changes in the distribution of fish species all over the world. Some 'winner' species have expanded their geographic range to the detriment of many 'loser' species (McKinney \& Lockwood 1999). Consequently, a worldwide homogenisation of biota has been observed for many taxonomic groups (Olden et al. 2004). Among the human influences on species dispersal, the creation of a canal connecting 2 marine biomes that evolved independently is certainly one of the most spectacular. These large-scale experiments provide unique opportunities to study the processes that shape biodiversity patterns and, in particular, the rate of biotic exchanges and the determinants of invasive success for introduced species (Smith et al. 2004).

The Suez Canal, completed in 1869, was the first artificial connection between 2 naturally separated seas the Mediterranean and Red Seas (Fig. 1). Hundreds of artificial canals have been created all over the world, but, with the exception of the Suez and Panama canals 


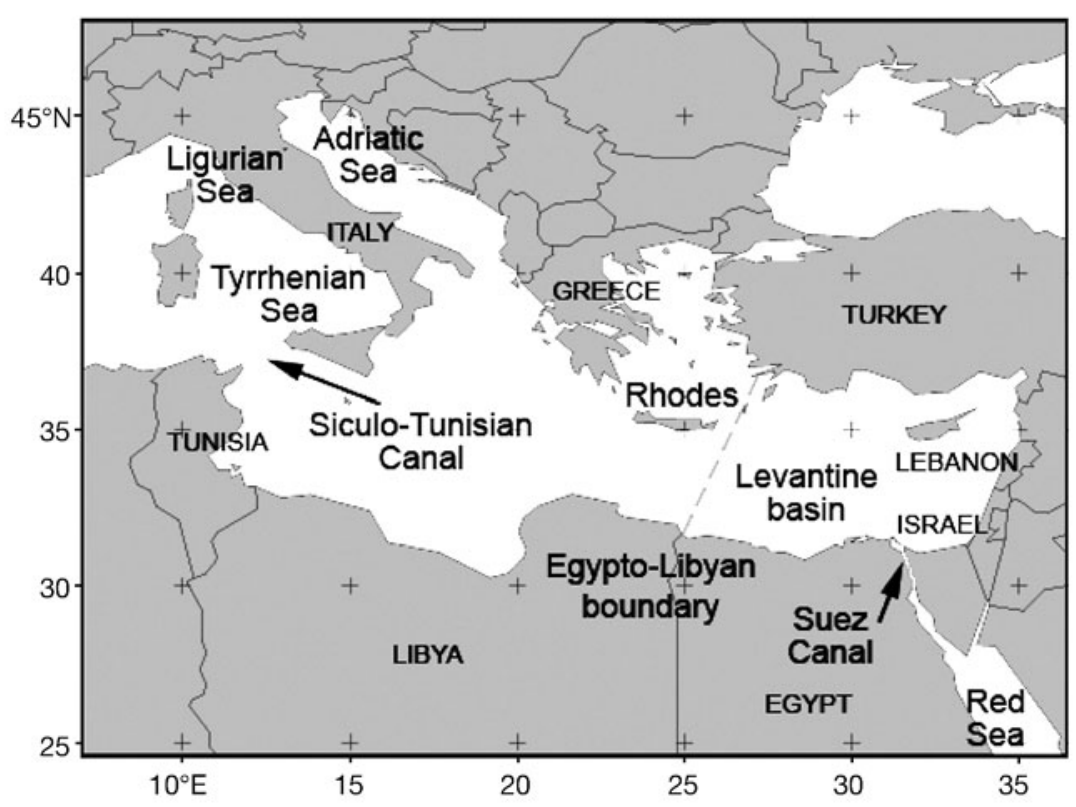

Fig. 1. Map of the Mediterranean Sea with the most important biogeographic features

(connecting 2 isolated seas), they connect a sea to a river (e.g. Canal du Midi in France connecting the Mediterranean Sea to the Garonne river), a sea to a lake (e.g. Saint Lawrence Seaways in Canada connecting the Atlantic Ocean to the Great Lakes), or 2 seas that are already naturally connected (e.g. Corinth Canal connecting the Ionian Sea and the Aegean Sea in Greece, Kiel Canal in Germany connecting the North Sea and the Baltic Sea) (The International Canal Monuments List 1996, www.icomos.org/studies/canals-toc.htm).

Just after completion of the Suez Canal in 1869, migration of Red Sea species into the Mediterranean Sea was blocked by the presence of hypersaline lakes inside the canal. After the salinity of these lakes equalized, fish species began migrating into the Mediterranean Sea (George \& Athanassiou 1967), where 63 species were subsequently recorded. Species migrating into the Mediterranean via the Suez Canal have been termed Lessepsian species in reference to the canal's architect, Ferdinand de Lesseps. In contrast, Goren \& Dor (1994) recorded only 15 anti-Lessepsian fishes. According to some authors, it remains difficult to list 'anti-Lessepsian' fishes (Tortenese 1984). Lessepsian flux of Red Sea fish species into the Mediterranean Sea is favoured by the dominant current in the Suez Canal, which flows South to North after the construction of the Aswan Dam in 1965, because the Red Sea is higher than the Eastern Mediterranean Sea (Hassan et al. 2003). In the context of global warming, most fish species are expected to shift their ranges of distribution polarwards, rather than adapt to warmer temperatures in situ (Huntley 1991).
The Mediterranean and Red Seas had very different faunal communities before completion of the Suez Canal, because the former is naturally connected to the Atlantic Ocean, while the latter is under the influence of the Indo-Pacific Ocean. Moreover, and in contrast to the Panama Canal (Smith et al. 2004), the Suez Canal connects 2 semiclosed seas with a high degree of endemism (8.8\% for the Mediterranean Sea) (Quignard \& Tomasini 2000). Thus, the impact of the Suez Canal on the biodiversity of both seas is potentially very important, because species assemblages are likely to become increasingly homogenised over time. In addition, local diversity loss can be expected if native species are endangered by the spread of exotic species. In our study, we focussed exclusively on the ability of introduced Lessepsian species to disperse in the Mediterranean Sea, not on the initial introduction of fishes from the Red Sea to the Mediterranean Sea (Duncan et al. 2001).

Some fish species succeeded in the colonisation of the entire Mediterranean, some remained limited to the eastern part of the basin, and others have never been recorded again after their first observation. Until now, the majority of studies on Lessepsian migration has been descriptive, reporting new occurrences of Lessepsian species (e.g. Golani 2000, Corsini et al. 2005, Golani \& Sonin 2006), setting up inventories (e.g. Torcu \& Mater 2000, Spanier 2000, Harmelin Vivien et al. 2005, Golani 2005), or describing the ecological impact of new arrivals on the Mediterranean fauna (e.g. Goren \& Galil 2005). A more challenging issue is to search for either species or habitat characteristics that can predict invasiveness (Goodwin et al. 1999, Colautti et al. 2006, Strauss et al. 2006). For instance, recent studies showed how some life history and ecological traits predispose certain species to establish themselves or to become invasive outside of their native range (Ruesink 2005). Furthermore, the identification of such biological traits common to invader species may allow us to anticipate future colonisations. Few studies have examined the factors determining the invasive success of Lessepsian fishes in their new environment (Ben Eliahu \& Golani 1990), and none have included all of the species ever recorded. In our study, we reconstructed the spatio-temporal dynamic of all Lessepsian fish species since their first record from the Mediterranean, and we tested whether their dispersal success can be related to functional traits (location in the water column, body size), life history traits (reproduction, growth), year of introduction into the Mediterranean, confamilial resistance and climate match. 


\section{MATERIALS AND METHODS}

Species list and calculation of dispersal rates. We compiled a list of Lessepsian fishes using and updating the CIESM Atlas (Golani et al. 2002). Our list includes 63 species (see Table 1 for the complete list). Since completion of this study, 3 new Lessepsian fishes have been recorded: Iniistius pavo (Corsini et al. 2006), Apogon queketti (Eryilmaz \& Dalyan 2006) and Decapterus russelli (Golani 2006), increasing the total number of Lessepsian fishes to 66 . These species were not included in our list or in our analysis, since they are less likely to have had enough time to spread along the Mediterranean coast and would consequently introduce bias into our analysis.

We compiled a bibliography of Lessepsian fish species recorded from the Mediterranean between 1896 and 2006 (Table 1). Each record was mapped using the Geographical Information System (GIS) software ArcView 3.3. Using this application, we measured the distance covered by each fish species along the coast line over a period of time, and then used this data to calculate their dispersal rate. Since it is not likely that dispersal is achieved by swimming along the entire coast, we did not include the coastline in bays and along islands of the Aegean Sea and the Gulf of Taranto in the distance covered by each species. Instead, the distances were measured in direct lines. Because most of the species show an asymmetrical pattern of dispersal between the southern and the northern Mediterranean-i.e. they do not disperse equally on both sides - we calculated and analysed a propagation speed for these two regions separately. As the number of records was not the same for all the species, two dispersal rates were estimated:

$$
\begin{gathered}
S_{T}^{n}=\frac{d_{T}^{n}}{Y_{f}^{n}-Y_{0}} ; \quad S_{T}^{s}=\frac{d_{T}^{s}}{Y_{f}^{s}-Y_{0}} \\
S_{t}^{n}=\frac{d_{t+1}^{n}-d_{t}^{n}}{Y_{t+1}^{n}-Y_{t}^{n}} ; S_{t}^{s}=\frac{d_{t+1}^{s}-d_{t}^{s}}{Y_{t+1}^{s}-Y_{t}^{s}}
\end{gathered}
$$

where $n$ is northern direction of dispersal, $s$ is southern direction of dispersal, $d_{t}^{n}$ is the total distance covered on the northern and $d_{t}^{s}$, the total distance covered on the southern side; $Y_{0}$ is the year of the first record in the Mediterranean Sea, $Y_{f}^{n}$, is the year of the record furthest

Table 1. Lessepsian species and their invasive success. YI: year of introduction, DS: dispersal success $(1=$ absence of dispersal, $2=$ weak dispersal, $3=$ strong dispersal), CM: climate match $(\mathrm{t}=$ tropical, st $=$ subtropical), PWC: position in the water column ( $\mathrm{p}=$ pelagic, $\mathrm{b}=$ benthic), ML: maximum total length $(\mathrm{cm})$, Pr: propagule $(\mathrm{p}=$ pelagic, $\mathrm{b}=$ benthic), CR: confamilial resistance, ND: dispersal on the northern side $(\mathrm{km})$, SD: dispersal on the southern side $(\mathrm{km})$. Data for CM, PWC, ML, Pr and CR from FishBase

\begin{tabular}{|c|c|c|c|c|c|c|c|c|c|c|c|}
\hline Species & Family & YI & DS & $\mathrm{CM}$ & PWC & ML & $\operatorname{Pr}$ & $\mathrm{CR}$ & ND & $\mathrm{SD}$ & Reference \\
\hline Atherinomorus lacunosus & Atherinidae & 1902 & 3 & st & $\mathrm{p}$ & 25 & $\mathrm{~b}$ & 3 & 1213 & 1953 & Tillier (1902) \\
\hline Alepes djedaba & Carangidae & 1927 & 2 & st & $\mathrm{b}$ & 40 & $\mathrm{p}$ & 15 & 2274 & 407 & Steinitz (1927) \\
\hline Coryogalops ochetica & Gobiidae & 1927 & 1 & $\mathrm{t}$ & $\mathrm{b}$ & 6 & $\mathrm{~b}$ & 49 & 0 & 0 & Norman (1927) \\
\hline Siganus rivulatus & Siganidae & 1927 & 3 & st & $\mathrm{b}$ & 27 & $\mathrm{~b}$ & 0 & 3680 & 1522 & Steinitz (1927) \\
\hline Stephanolepis diaspros & Monacanthidae & 1927 & 3 & $\mathrm{t}$ & $\mathrm{b}$ & 25 & $\mathrm{p}$ & 0 & 2245 & 2548 & Steinitz (1927) \\
\hline Leiognathus klunzingeri & Leiognathidae & 1931 & 3 & $\mathrm{t}$ & $\mathrm{b}$ & 110 & $\mathrm{p}$ & 0 & 5500 & 933 & Spicer (1931) \\
\hline Sphyraena chrysotaenia & Sphyraenidae & 1931 & 3 & $\mathrm{t}$ & $\mathrm{p}$ & 30 & $\mathrm{p}$ & 3 & 5435 & 1702 & Spicer (1931) \\
\hline Parexocoetus mento & Exocoetidae & 1935 & 3 & $\mathrm{t}$ & $\mathrm{p}$ & 11 & $\mathrm{~b}$ & 4 & 3700 & 2834 & Bruun (1935) \\
\hline Scomberomorus commerson & Scombridae & 1935 & 3 & $\mathrm{t}$ & $\mathrm{p}$ & 240 & $\mathrm{p}$ & 13 & 859 & 894 & Hornell (1935) \\
\hline Herklotsichthys punctatus & Clupeidae & 1943 & 2 & st & $\mathrm{p}$ & 9 & $\mathrm{p}$ & 8 & 912 & 541 & Bertin (1943) \\
\hline Apogon pharaonis & Apogonidae & 1947 & 2 & st & $\mathrm{b}$ & 10 & $\mathrm{~b}$ & 2 & 1600 & 0 & Haas \& Steinitz (1947) \\
\hline Sargocentrum rubrum & Holocentridae & 1947 & 3 & st & $\mathrm{b}$ & 32 & $\mathrm{p}$ & 0 & 1666 & 1522 & Haas \& Steinitz (1947) \\
\hline Callionymus filamentosus & Callionymidae & 1953 & 2 & st & $\mathrm{b}$ & 20 & $\mathrm{p}$ & 7 & 1452 & 0 & Ben Tuvia (1953) \\
\hline Cynoglossus sinusarabici & Cynoglossidae & 1953 & 2 & $\mathrm{t}$ & $\mathrm{b}$ & 10 & $\mathrm{p}$ & 3 & 895 & 592 & Ben Tuvia (1953) \\
\hline Platycephalus indicus & Platycephalidae & 1953 & 2 & st & $\mathrm{b}$ & 100 & $\mathrm{p}$ & 0 & 572 & 420 & Ben Tuvia (1953) \\
\hline Saurida undosquamis & Synodontidae & 1953 & 3 & st & $\mathrm{b}$ & 50 & $\mathrm{p}$ & 1 & 3434 & 1878 & Ben Tuvia (1953) \\
\hline Himantura uarnak & Dasyatidae & 1955 & 2 & st & $\mathrm{b}$ & 200 & $\mathrm{~b}$ & 6 & 912 & 0 & Ben Tuvia (1955) \\
\hline Siganus luridus & Siganidae & 1955 & 3 & st & $\mathrm{b}$ & 30 & b & 0 & 4500 & 3407 & Ben Tuvia (1964) \\
\hline Etrumeus teres & Dussumieriidae & 1963 & 2 & st & $\mathrm{p}$ & 30 & $\mathrm{p}$ & 8 & 2800 & 424 & Whitehead (1963) \\
\hline Hyporhamphus affinis & Hemiramphidae & 1964 & 1 & $\mathrm{t}$ & $\mathrm{b}$ & 38 & $\mathrm{~b}$ & 1 & 0 & 0 & George et al. (1964) \\
\hline Tylosorus choram & Belonidae & 1967 & 1 & $\mathrm{t}$ & $\mathrm{b}$ & 120 & $\mathrm{~b}$ & 3 & 0 & 0 & Parin (1967) \\
\hline
\end{tabular}
unless otherwise indicated by superscripts 
Table 1 (continued)

\begin{tabular}{|c|c|c|c|c|c|c|c|c|c|c|c|}
\hline Species & Family & YI & DS & $\mathrm{CM}$ & PWC & ML & $\operatorname{Pr}$ & $\mathrm{CR}$ & ND & $\mathrm{SD}$ & Reference \\
\hline Epinephelus coïoïdes & Serranidae & 1969 & 3 & st & $\mathrm{b}$ & 120 & $\mathrm{p}$ & 12 & 415 & 0 & Ben Tuvia \& Lourie (1969) \\
\hline Epinephelus malabaricus & Serranidae & 1969 & 1 & $\mathrm{t}$ & $\mathrm{b}$ & 234 & $\mathrm{p}$ & 12 & 0 & 0 & Ben Tuvia \& Lourie (1969) \\
\hline Crenidens crenidens & Sparidae & 1970 & 3 & st & $\mathrm{b}$ & 30 & $\mathrm{p}$ & 22 & 552 & 1522 & Lourie \& Ben Tuvia (1970) \\
\hline Rastrelliger kanagurta & Scombridae & 1970 & 1 & $\mathrm{t}$ & $\mathrm{p}$ & 35 & $\mathrm{p}^{\mathrm{A}}$ & 13 & 0 & 0 & Collette (1970) \\
\hline Terapon puta & Teraponidae & 1976 & 2 & $\mathrm{t}$ & $\mathrm{p}$ & 16 & $\mathrm{p}$ & 0 & 744 & 580 & Ben Tuvia (1976) \\
\hline Sillago sihama & Sillaginidae & 1977 & 2 & $\mathrm{t}$ & $\mathrm{b}$ & 30 & $\mathrm{p}$ & 0 & 762 & 790 & Mouneimne (1977) \\
\hline Spratelloides delicatulus & Clupeidae & 1978 & 1 & $\mathrm{t}$ & $\mathrm{p}$ & 7 & $\mathrm{~b}$ & 8 & 0 & 0 & Ben Tuvia (1978) \\
\hline Lutjanus argentimaculatus & Lutjanidae & 1979 & 1 & st & $\mathrm{b}$ & 150 & $\mathrm{p}$ & 0 & 0 & 0 & Mouneimne (1979) \\
\hline Pempehris vanicolensis & Pempheridae & 1979 & 3 & $\mathrm{t}$ & $\mathrm{b}$ & 20 & $\mathrm{p}$ & 0 & 2153 & 2834 & Mouneimne (1979) \\
\hline Muraenesox cinereus & Muraenesocida & 1982 & 1 & st & $\mathrm{b}$ & 16 & $\mathrm{p}$ & 1 & 0 & 0 & Golani \& BenTuvia (1982) \\
\hline Oxyurichthys petersi & Gobiidae & 1983 & 2 & $\mathrm{t}$ & $\mathrm{b}$ & 18 & $\mathrm{~b}$ & 49 & 912 & 0 & Ben Tuvia (1983) \\
\hline Rachycentron canadum & Rachycentridae & 1986 & 1 & st & $\mathrm{b}$ & 200 & $\mathrm{p}$ & 0 & 0 & 0 & Golani \& Ben Tuvia, (1986) \\
\hline Papilloculiceps longiceps & Platycephalidae & 1990 & 1 & $\mathrm{t}$ & $\mathrm{b}$ & 70 & $\mathrm{p}$ & 0 & 0 & 0 & Golani \& Ben Tuvia (1990) \\
\hline Pteragogus pelycus & Labridae & 1992 & 2 & st & $\mathrm{b}$ & 15 & $\mathrm{p}$ & 19 & 1666 & 0 & Golani \& Sonin (1992) \\
\hline Pterois miles & Scorpaenidae & 1992 & 1 & $\mathrm{t}$ & $\mathrm{b}$ & 35 & $\mathrm{p}$ & 8 & 0 & 0 & Golani \& Sonin (1992) \\
\hline Rhabdosargus haffara & Sparidae & 1992 & 1 & $\mathrm{t}$ & $\mathrm{b}$ & 35 & $\mathrm{p}$ & 22 & 0 & 0 & Golani (1992) \\
\hline Sphyraena flavicauda & Sphyraenidae & 1992 & 3 & $\mathrm{t}$ & $\mathrm{b}$ & 60 & $\mathrm{p}$ & 3 & 1666 & 2209 & Golani (1992) \\
\hline Rhynchoconger trewavasae & Congridae & 1993 & 1 & st & $\mathrm{b}$ & 57 & $\mathrm{p}$ & 3 & 0 & 0 & Ben Tuvia (1993) \\
\hline Chilomycterus spilostylus & Diodontidae & 1993 & 1 & $\mathrm{t}$ & $\mathrm{b}$ & 34 & $\mathrm{p}$ & 0 & 0 & 0 & Golani (1993) \\
\hline Abudefduf vaigiensis & Pomacentridae & 1998 & 3 & $\mathrm{t}$ & $\mathrm{b}$ & 20 & $\mathrm{~b}$ & 2 & 8198 & 0 & Goren \& Galil (1998) \\
\hline Fistularia commersonii & Fistularidae & 2000 & 3 & $\mathrm{t}$ & $\mathrm{b}$ & 160 & $\mathrm{p}$ & 1 & 3482 & 2153 & Golani (2000) \\
\hline Hippocampus fuscus & Syngnathidae & 2001 & 2 & $\mathrm{t}$ & $\mathrm{b}$ & 14.4 & $\mathrm{~b}$ & 12 & 1259 & 520 & Golani \& Fine (2002) \\
\hline Plotosus lineatus & Plotosidae & 2001 & 1 & $\mathrm{t}$ & $\mathrm{b}$ & 32 & $\mathrm{~b}$ & 0 & 0 & 0 & Golani (2002) \\
\hline Heniochus intermedius & Chaetodontidae & 2002 & 1 & $\mathrm{t}$ & $\mathrm{b}$ & 20 & $\mathrm{p}$ & 2 & 0 & 0 & Gökoglu et al. (2003) \\
\hline Scarus ghobban & Scaridae & 2002 & 2 & $\mathrm{t}$ & $\mathrm{b}$ & 90 & $\mathrm{p}$ & 2 & 240 & 0 & Goren \& Aronov (2002) \\
\hline
\end{tabular}

from the Suez Canal on the northern and $Y_{f}^{s}$ on the southern side, respectively; and $Y_{t^{\prime}}^{n} Y_{t+1}^{n}, Y_{t}^{s}, Y_{t+1}^{s}$, are the record in year $t$ and the following record $(t+1)$ on the northern side and on the southern side, respectively.

Eq. (1) 1 was used to calculate the propagation speed $S_{T}$ between the first record and that furthest from the Suez Canal, expressed in $\mathrm{km} \mathrm{yr}^{-1}$. Eq. (2) was used to reconstruct the chronological series of the dispersal speed $S_{t}$ per record interval, i.e. at each new record.

Since dispersal rates were not accurate enough to be included in our statistical analysis, we used them only for a descriptive purpose. In order to provide a trend for the dispersal rate, we plotted the distance crossed against time. However, since this was only possible where the number of records was sufficient (at least 3) and this requirement was not met for the southern side of the Mediterranean, we produced the plots only for the northern side.
In order to investigate the ecological correlates of dispersal success, we built a categorical variable summarizing the species ability to spread over the Mediterranean Sea. The 63 fish species (Table 1) were assigned to 3 categories: (1) absence of dispersal, including the species that were recorded once and have never been recorded since; (2) weak dispersal, including species that were not able to spread beyond the biogeographical boundaries of the Levantine basin, i.e. the island of Rhodes (northern side) and the Egypto-Libyan boundary (southern side); and (3) strong dispersal, including species distributed beyond the above boundaries (Fig. 1). Dispersal success was estimated independently from observed abundances. We considered that even if a record includes only a small number of specimens, it reveals the spread of the species. Moreover, as most of the species follow a positive dispersal range-abundance 
relationship (Gaston 2003), we hypothesized that spatial dispersal and total abundance in the Mediterranean Sea may evolve proportionally.

Ecological variables. We compiled a database containing variables that are likely to influence invasion success for each of the species: climate match, position in the water column, maximum length, presence of propagules, confamilial resistance, and year of introduction.

Climate match: Invasion success of some exotic species has been shown to be positively related to the match between native and colonised environment (Wolf et al. 1998, Duncan et al. 2001). As this information often lacks large-scale studies, the climate match has been explored by comparing the latitude of the native range to the introduction latitude (Blackburn \& Duncan 2001). A species that is introduced at a latitude very close to its native latitude is more likely to experience rather similar thermal conditions, and thus more likely to establish successfully. Based on these assumptions, subtropical species are more likely to disperse over the Mediterranean Sea than tropical species because of the difference in their tolerance to cold water. For our study, each species was considered either as a tropical species, i.e. preferring water temperatures over $20^{\circ} \mathrm{C}$, or as a subtropical species, i.e. preferring water temperatures between $10^{\circ} \mathrm{C}$ and $20^{\circ} \mathrm{C}$, in their original environment. These temperature preferences were taken from FishBase (Froese \& Pauly 2006).

Position in the water column: Pelagic fishes are more prone to undertaking migrations than benthic species. The former have a higher swimming performance than the latter, due to their hydrodynamic body shape (e.g. Bardin \& Pont 2002). Thus, we hypothesized that pelagic species a have higher dispersal ability than benthic species. Information on the position in the water column of each species was taken from FishBase (Froese \& Pauly 2006).

Maximum length: Fish species with rapid growth and a high reproduction rate may disperse better because invaders have to breed quickly to avoid extinction (McArthur \& Wilson 1967). Thus, species with early sexual maturity are more likely to establish themselves in a new environment than others. Since sexual maturity is highly positively correlated to the maximum length (Peters 1983, Savage et al. 2004), we assumed that small species with earlier sexual maturity are more likely to disperse over the Mediterranean Sea than larger species. Maximum length data were taken from FishBase (Froese \& Pauly 2006).

Propagules: Major oceanic currents may allow certain marine species to disperse over extremely long distances (Shanks et al. 2003). Species whose propagules have the ability to disperse more widely are expected to achieve a wider geographic range (Emlet 1995, Gaston 2003). Fish propagules are larvae and eggs. According to Leis
(1991), factors affecting larval dispersal are behaviour, swimming speed and duration of the pelagic larval phase. Because data for the larvae of all species in this study were not available, we considered only eggs, even though some demersal spawners have pelagic larvae and their dispersal ability is not less than that of pelagic spawners. We hypothesized that fish species with pelagic eggs have a wider geographic range than species with benthic eggs. Although some benthic fishes invest more in parental care, they are weak dispersers. Conversely, one may also argue that parental care increases larval survival and could therefore serve to enhance fish population establishment. Therefore, these 2 alternative hypotheses were tested. We also investigated which type of propagule, pelagic or benthic, disperses better in terms of distance covered by each species on the northern vs. the southern side of the Mediterranean. This method has the advantage of avoiding the bias of detectability, because species with pelagic propagules and species with benthic propagules have the same probability of being captured. Information about propagule type (pelagic or benthic) was taken from FishBase (Froese \& Pauly 2006) and existing literature. Where data about fish propagules were not available for a species we used information from the family level, making the assumption that co-familiar species are consistent for this trait.

Confamilial resistance: We hypothesized that invading species with no or very few confamilial counterparts in the Mediterranean Sea would have a higher dispersal success rate than species which encounter close relatives because of the absence of competition for resources (habitat and food), based on observations by Davis et al. (2000) and Strauss et al. (2006). On the other hand, one could maintain that the dispersal potential of invasive species having confamilial species already installed in the Mediterranean Sea may be facilitated due to the availability of suitable habitats. This 'confamilial resistance' hypothesis was initially proposed by Darwin (1859). We tested these 2 opposite hypotheses by comparing the taxonomy of species coming from the Red Sea to the Mediterranean species pool. The confamilial resistance was estimated based on the number of Mediterranean species found in the family of each Lessepsian species.

Year of introduction: One potential confounding variable in our study is the year of introduction. Species introduced at the beginning of the century were more likely to disperse than more recently introduced species. For the purpose of our study, the year of first record was treated as the year of introduction into the Mediterranean.

Statistical analyses. We carried out 2 types of complementary analyses. First, we tested the effect of each variable on the dispersal success individually. Given 
that our dataset was limited (63 species), and that the assumptions of parametric tests were not met by our data, we used a non-parametric chi-squared test for evaluating the qualitative relationships between ecological variables and dispersal success. We used the modalities 'tropical fish' (t) and 'subtropical fish' (st) for the climate match, the modalities 'benthic fish' (b) and 'pelagic fish' ( $p$ ) for the position in the water column, and the modalities 'benthic eggs' (b) and 'pelagic eggs' (p) for the type of propagule. For the quantitative variables (mean values of maximum fish length: ML, confamilial resistance: $C R$, year of introduction: $Y I)$, we used the non-parametric Kruskal-Wallis test. This test was also used to analyse the influence of the propagule type on the relative dispersal on the northern and southern side of the Mediterranean Sea, using the difference $d^{n}-d^{s}$ as a predicted variable (where $d^{n}$ is the distance covered on the northern side and $d^{s}$ is the distance covered on the southern side). All statistical tests were performed using the software Minitab 12.2.

In order to prioritize the factors related to dispersal success (coded as a binary variable: absence or presence of dispersal), and to investigate potential subsequent interactions between factors, we followed a multiple logistic regression approach (Generalized Linear Model, GLM, with a binomial error and a logit link) in a second step. Starting with a maximal model including all 6 factors listed above and all second order interactions, the relative importance of factors was assessed using a backward selection procedure. The significance of the increase in deviance resulting from the deletion of a term in the model was estimated using chi-squared deletion tests (Crawley 2007). The minimal adequate model was selected as the one containing nothing but significant terms. We used the commands 'glm', 'summary' and 'anova' from the $\mathrm{R}$ statistical and programming environment (R Development Core Team 2007) to parameterize and select the models and to perform analyses of deviance.

Surface temperature map. Using the GIS software (ArcView 3.3), we generated a map using data from the National Climatic Data Center (NCDC) National Operational Model Archive and Distribution System Meteorological Data Server (NOMADS) of the US National Oceanic and Atmospheric Administration (NOAA) Satellite and Information Service (at www. osdpd.noaa.gov/PSB/EPS/SST/al_climo_mon.html).

\section{RESULTS}

The first record of a Lessepsian fish species in the Mediterranean, Atherinomorus lacunosus, is attributed to Tillier (1902). The most recent record we took into account for our analysis is from 2005, Tylerius spinosissimus (Corsini et al. 2005). The Lessepsian fish arrivals in the Mediterranean Sea continually increased between the 1930s and the 1950s (Fig. 2a). We observed another period of increased dispersal of Lessepsian species starting in 1980 from an average of 0.7 for the 1980s to 2 species $\mathrm{yr}^{-1}$ for the most recent years (Fig. 2a). Lessepsian species belonged to 45 families and 57 genera (Table 1). The most frequently represented families are the Tetraodontidae with 5 species, followed by the Clupeidae with 4 species and the Gobiidae and the Platycephalidae with 3 species each. Overall, 51 species are benthic while 12 are considered to be pelagic. The maximum size of these species varied from $4 \mathrm{~cm}$ to $240 \mathrm{~cm}$, the most frequent maximum size (mode of distribution) being between $20 \mathrm{~cm}$ and $30 \mathrm{~cm}$.

\section{Dispersal rates of Lessepsian fishes}

The western-most record of a Lessepsian species on the northern side of the Mediterranean was that of Pomadasys stridens in the Ligurian Sea (Torchio 1969). On the southern side of the Mediterranean Sea, the western most record was that of Fistularia commersonii in Sardinia (Pais et al. 2007). The species propagation rate analysis revealed that 20 species did not successfully
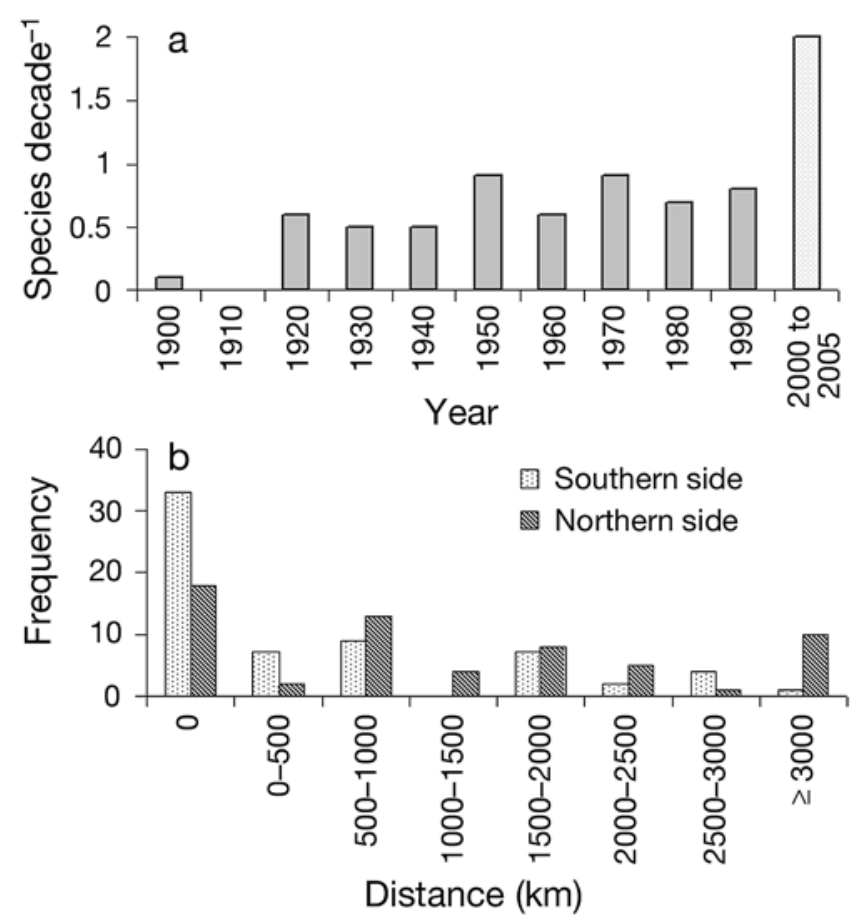

Fig. 2. (a) Introduction of Lessepsian fish species in the Mediterranean Sea over the study period. Bars represent the annual mean number of Lessepsian introductions per decade. The last column only includes values from 2000 to 2005; (b) Observation frequency (number of Lessepsian species) and distance from entry point (Suez Canal) on the northern and southern sides 
disperse after they were first recorded. 24 species were limited to the coast of the Levantine basin while 19 species, corresponding to $30 \%$ of the Lessespian pool, succeeded in dispersing beyond those limits.

The number of species observations and distance from their point of entry on the northern and southern sides of the Mediterranean are shown in Fig. 2b., illustrating the different dispersal rates for the two areas. We did not compare these 2 distributions statistically since fishing effort and scientific investigation are not comparable between the 2 sides. The dispersal rate was calculated for all species that were recorded at least 3 times (16 species): on average, Lessepsian species spread at a rate of $122 \mathrm{~km} \mathrm{yr}^{-1}(\mathrm{SE}=2.1 \mathrm{~km}$ $\mathrm{yr}^{-1}$ ) on the northern side of the Mediterranean Sea.

Dispersal rate appeared to increase over time for the species restricted to the Levantine basin, i.e. those assigned to the category 'weak dispersal' (e.g. Apogon pharaonis Fig. 3a, Callionymus filamentus Fig. 3i, Hemiramphus far Fig. 3c, Herklotsichthys punctatus Fig. 3d, Lagocephalus suezensis Fig. 3e and Petroscirtes ancylodon Fig. 3f). Conversely, for the species
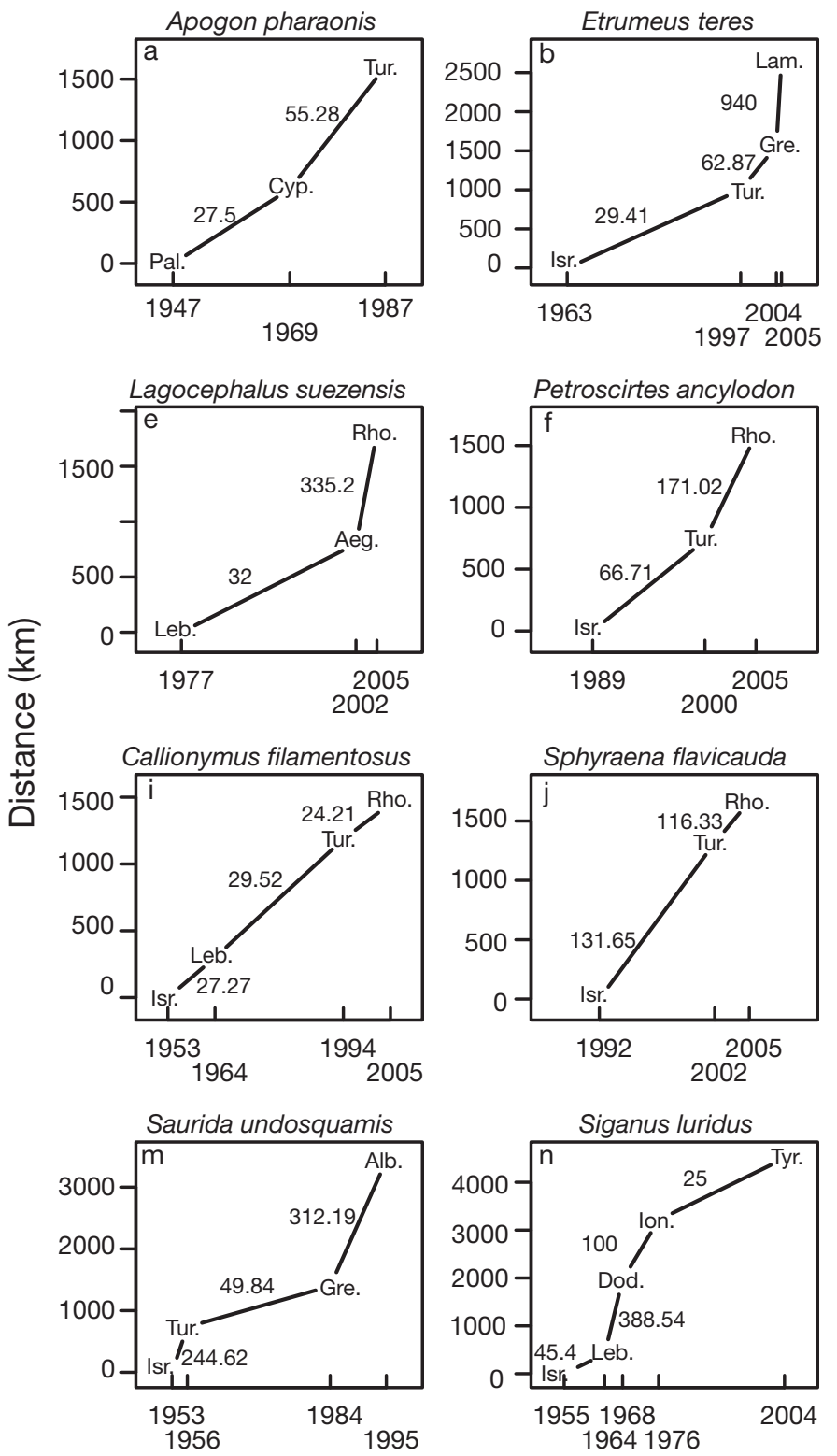
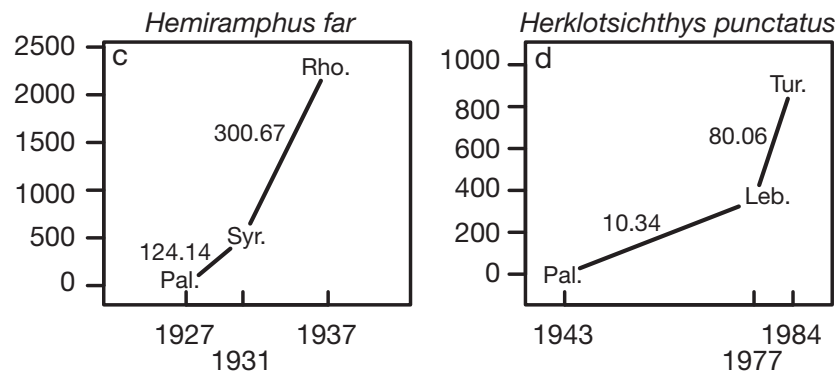

Scomberomorus commerson
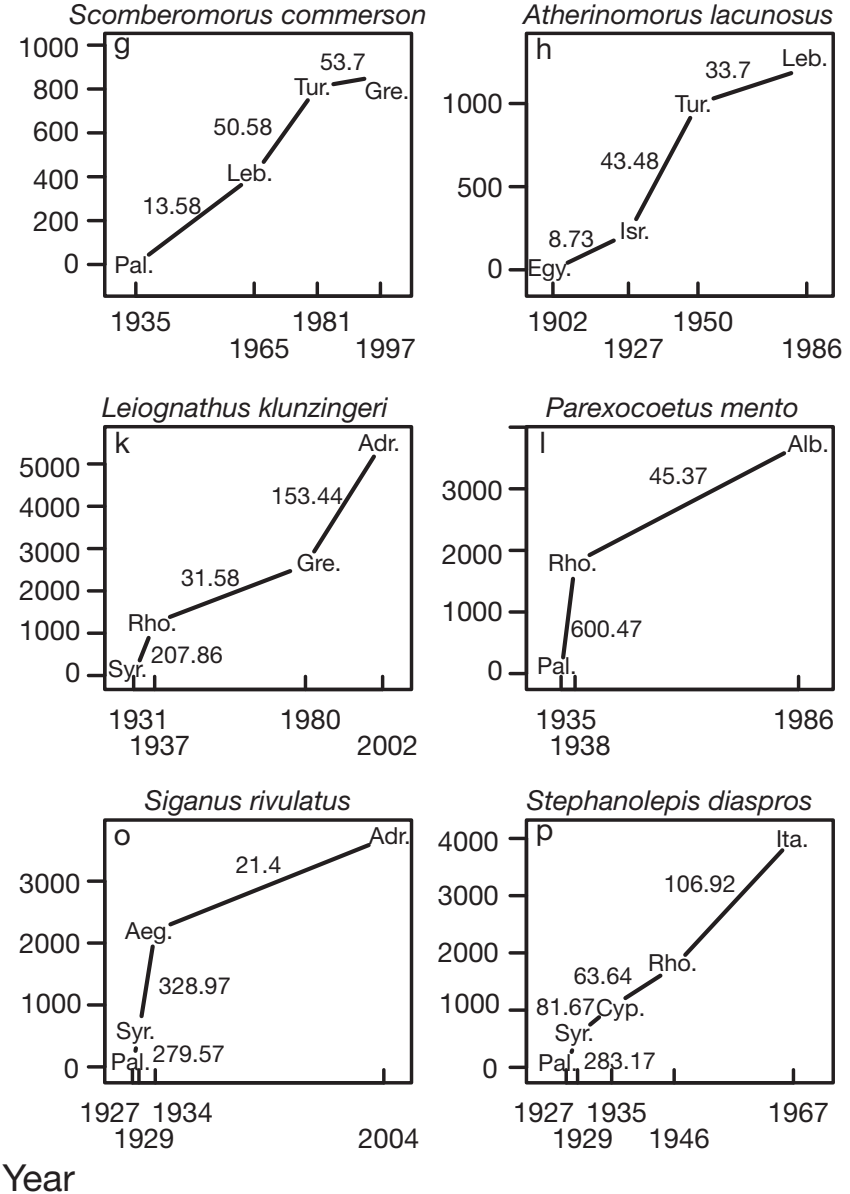

Stephanolepis diaspros

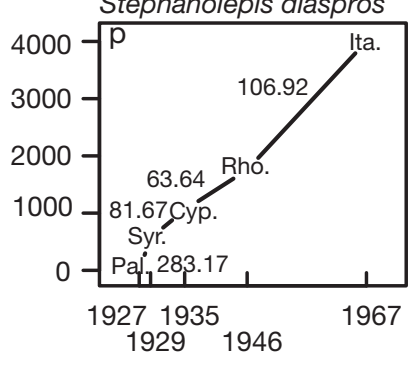

Fig. 3. Dipersal of 16 Lessepsian species recorded $\geq 3$ times in the northern Mediterranean. Location of new records and average speed $\left(\mathrm{km} \mathrm{yr}^{-1}\right)$ of dispersal between locations indicated within and beside curves, respectively. Places are: Adriatic Sea (Adr.), Aegean Sea (Aeg.), Albania (Alb.), Cyprus (Cyp.), Dodecanese (Dod.), Egypt (Egy.), Greece (Gre.), Ionian Sea (Ion.), Israel (Isr.), Italy (Ita.), Lampedusa (Lam.), Lebanon (Leb.), Palestine (Pal.), Rhodes (Rho.), Syria (Syr.), Turkey (Tur.) and Tyrrhenian Sea (Tyr.) 
that spread beyond the limits of the Levantine (strong dispersal) towards the northern side of the Mediterranean Sea, the dispersal speed decreased at transitional zones between basins (e.g. Leiognathus klunzingeri Fig. 3k, Parexocoetus mento Fig. 31, Siganus luridus Fig. 3n, and Siganus rivulatus Fig. 3o) when they reached the Adriatic and the Tyrrhenian seas. For instance, the dispersal rate of L. klunzingeri (Fig. 3k) was $207.8 \mathrm{~km} \mathrm{yr}^{-1}$ until the species reached the island of Rhodes, and dropped to $31.6 \mathrm{~km} \mathrm{yr}^{-1}$ between the island of Rhodes and the eastern coast of Greece while crossing the Aegean Sea. After this barrier was crossed, the speed increased again to $153.4 \mathrm{~km} \mathrm{yr}^{-1}$ towards the Adriatic Sea. During the spread of P. mento from the island of Rhodes to Albania, the dispersal speed dropped from $600.4 \mathrm{~km} \mathrm{yr}^{-1}$ to $72.9 \mathrm{~km}$ $\mathrm{yr}^{-1}$. The same deceleration was observed for $S$. luridus during its transition from the Aegean Sea to the Adriatic Sea, where the dispersal rate decreased to less than a 7 th of its previous value (Fig. 3n). It appears that the transition between different water bodies acts as a geographical barrier.

Of the 16 species for which dispersal rate trends were reconstructed, and excluding those that decelerated when crossing geographical barriers (6 species), $70 \%$ accelerated their propagation after the 1980s, with the average speed increasing about 5 -fold. The species whose dispersal rate decelerated before reaching the island of Rhodes are Atherinomorus lacunosus, Callionymus filamentus and Sphyraena flavicauda.

\section{Variables related to dispersal}

Among the 6 variables tested, only the climate match (CM) and year of introduction (YI) were significantly correlated with the 3 dispersal success categories (absence, weak or strong dispersal, Table1). Tropical species spread less than expected by chance, while the spread of subtropical species, dispersing over areas outside of the Levantine basin, was greater than expected. For example, Oxyurichthys petersi (Fig. 4a), a tropical species, was limited to the eastern part of the Mediterranean Sea and showed weak dispersal, while the subtropical Siganus luridus (Fig. 4b) spread over the western part and showed strong dispersal. In addition, it appears that species that dispersed successfully were those that had been introduced a long time ago (Table 2). Species with pelagic propagules were more likely to disperse over the northern side than species with benthic propagules (Table 2).

The minimal adequate model from the logistic regression analysis predicted dispersal success (coded as a binary variable: absence or presence of dispersal)
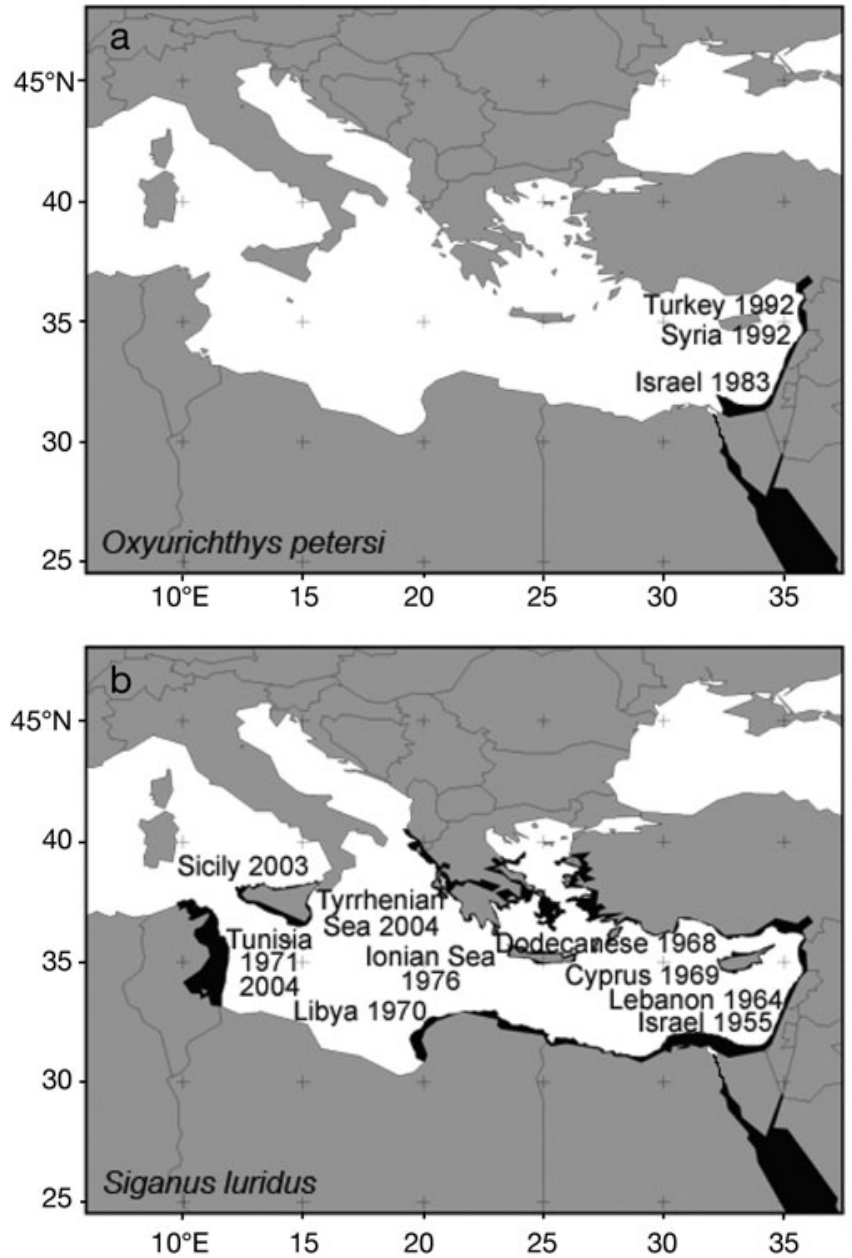

Fig. 4. Oxyurichthys petersi and Siganus luridus. Two examples of propagation (black shading) in the Mediterranean Sea: (a) O. petersi, a tropical species with weak dispersal limited to the eastern part, (b) $S$. luridus, a subtropical species with strong dispersal over the western Mediterranean

as a function of YI, CM, and the interaction between these 2 factors (CM:YI, Table 3). The 'interaction' term represents the joint multiplicative effect of the year of introduction and climate match and indicates the interactive influences of these variables on the dispersal rate beyond the corresponding main effects. These results corroborate and refine the conclusions from the independent tests for each factor: Lessepsian fishes with an earlier year of introduction and a subtropical origin are more likely to disperse successfully (Table 3). However, the GLM results (factor coefficients) reveal that climate match is the major influence on the dispersal success compared to the year of introduction. In addition, the significant interaction term showed that the year of introduction does not have the same effect on subtropical and tropical species: for tropical species, the year of introduction 
Table 2. Chi-squared (CS) and Kruskal-Wallis (KW) tests for the effect of predictors on the dispersal success of Lessepsian fishes in the Mediterranean Sea. CM: climate match, PWC: position in the water column, ML: maximum total length, Pr: propagule type, Pr/NS: effect of the propagule type on the dispersal on the northern side versus the southern side, CR: confamilial resistance, YI: year of introduction. $\left({ }^{\mathrm{ns}}\right)$ not significant, ${ }^{*} \mathrm{p}<0.05,{ }^{* *} \mathrm{p}<0.01$

\begin{tabular}{|lccccccc|}
\hline & CM & PWC & ML & Pr & Pr/NS & CR & YI \\
\hline CS & $7.48^{*}$ & $1.67^{\text {ns }}$ & & $1.19^{\text {ns }}$ & & & \\
KW & & & $40.3^{\text {ns }}$ & & $5.08^{*}$ & $5.9^{\text {ns }}$ & $10.6^{* *}$ \\
\hline
\end{tabular}

had a near to linear negative effect, whereas it had a logistic-type effect for subtropical species (Fig. 5). In summary, our results indicate that all subtropical species introduced before 1980 (Fig. 5: inflexion point of the logistic curve) have successfully dispersed, while the probability of tropical species to disperse through the Mediterranean decreases linearly with their date of introduction.

\section{DISCUSSION}

\section{Dispersal rates}

Our results revealed that, of the invasive species for which the dispersal rate could be assessed, the dispersal of 6 species had a logistic curve shape (Leiognathus klunzingeri, Fig. 3k; Parexocoetus mento Fig. 31, Saurida undosquamis Fig. 3m, Siganus luridus Fig. 3n, Siganus rivulatus Fig. 3o and Stephanolepis diaspros Fig. 3p), which is typical for invasive species (Hengeveld 1989, Silva et al. 2002). The slowing of the dispersal rate near the inflexion in the curve happens around the island of Rhodes, which appears critical for Lessepsian species. The island of Rhodes lies at the transition between the warm Levant basin and the cooler western part of the Mediterranean Sea. At this point, the mean sea surface temperature drops from $20.8^{\circ} \mathrm{C}$ to $18.95^{\circ} \mathrm{C}$ (Fig. 6). The island of Rhodes represents a thermal barrier that decelerates species dispersal. This

Table 3. Selected logistic regression model relating dispersal success to climate match and year of introduction. df: degrees of freedom, Dev: deviance, \%Exp: percent of explained deviance, RD: residual deviance, CM: climate match, YI: year of introduction

\begin{tabular}{|lccccccc|}
\hline Factors & Estimate & df & Dev & $\% \operatorname{Exp}$ & $\mathrm{R}$ df & $\mathrm{RD}$ & $\mathrm{p}(>\mid$ chil $)$ \\
\hline Constant & 349.02 & & & & 62 & 78.74 & \\
CM & -313.81 & 1 & 3.96 & 28.42 & 61 & 74.77 & 0.04 \\
YI & -0.17 & 1 & 8.664 & 32.15 & 60 & 66.11 & 0.003 \\
CM:YI & 0.1584 & 1 & 8.49 & 36.89 & 59 & 57.61 & 0.004 \\
\hline
\end{tabular}

hypothesis was consistently supported by our data, because most of the species reaching the western basin (L. klunzingeri, P. mento, S. luridus and S. rivulatus) slowed down during their passage from one basin to another (Fig. 3). This general trend supports the idea that observed decreases in dispersal rates are linked to the passage through thermal barriers. However, we used rough estimations of dispersal rates for our study that cannot be used to make predictions about future dispersal of Lessepsian fishes.

\section{Variables correlated with dispersal}

Six variables, potentially correlated with dispersal success, were examined: year of introduction, climate match, location in the water column, maximum fish length, propagule type and confamilial resistance. Among these ecological variables, climate match and year of introduction showed a significant relationship with dispersal success when split into 3 categories: subtropical species and species introduced early had an advantage in the dispersal. When we tested the relative dispersal on both sides of the Mediterranean, it appeared that species with pelagic propagules were more prone to disperse on the northern side than species with benthic propagules. By using logistic regression we showed that the dispersal success of Lessepsian fishes is significantly explained by the climate match (main factor), the year of introduction, and the interaction of these two factors (Table 3). More precisely, we demonstrated that the year of introduction does not have the same effect on subtropical and tropical species (Fig. 5).

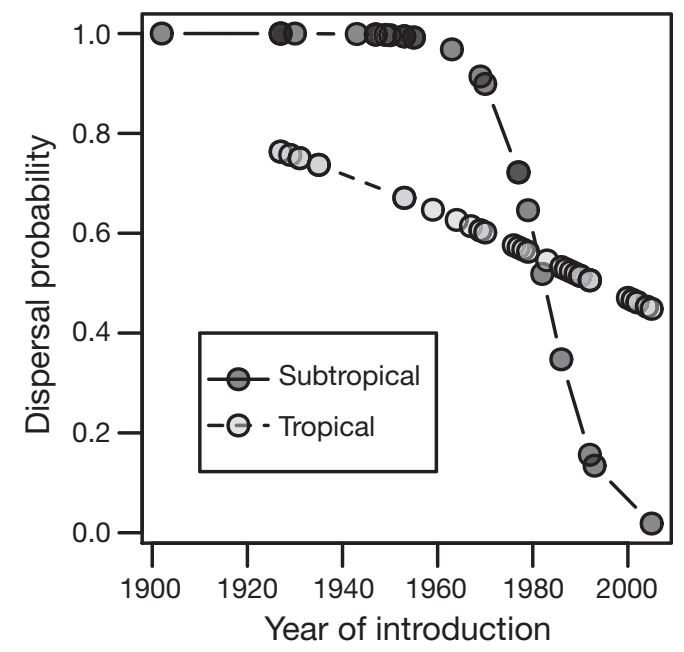

Fig. 5. Logistic model predicting probability of dispersal success for Lessepsian species by year of introduction and species origin (subtropical or tropical). The statistics of the model are summarized in Table 3 


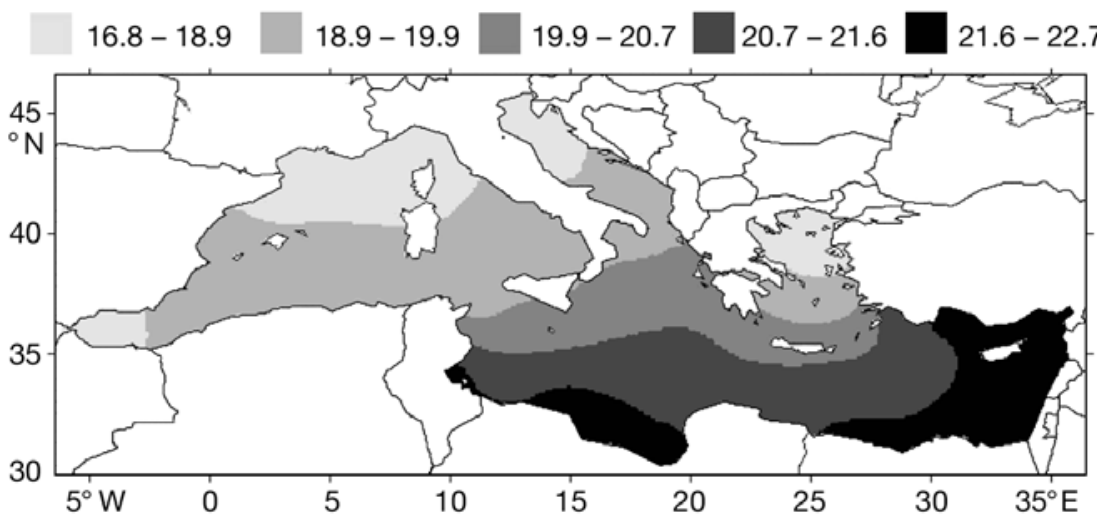

Fig. 6. Mean sea surface temperature $\left({ }^{\circ} \mathrm{C}\right)$ in the Mediterranean Sea for the year 2000 (data from NCDC NOMADS Meteorological Data Server, NOAA)

confirmed by a recent study (Hamad et al. 2005) (Fig. 7). Pelagic propagules are more exposed to this pressure than benthic propagules, which may explain why species with pelagic propagules are more likely to disperse over the northern side, while species with benthic propagules disperse equally over the southern and northern sides. Therefore, the counterclockwise circulation in the Levantine basin appears to be the main forcing factor in the propagation of Lessepsian species with pelagic eggs.

Propagule pressure, in terms of size and number of individuals released, is emerging as a strong correlate of inva-

Our results are in agreement with Blackburn \& Duncan (2001), who also explored climate match by comparing the latitude of birds' native ranges to their introduction latitude. Their findings, as well as ours, suggest that dispersal success of exotic species depends on the suitability of the abiotic environment at their introduction site and that climate match is a useful tool for examining a species' potential success. Temperatures in the Mediterranean seem more suitable for subtropical than for tropical species. We found that subtropical fishes tend to spread more widely than tropical ones, which have more difficulties (more time needed) to extend away from their introduction site, due to minimal thermal tolerances.

The ability of species to establish themselves in new environments, to recover from disturbances and to adapt to varying environmental conditions, depends on their dispersal capacity and the amount of time passed since introduction. These are 2 fundamental elements of population ecology (Bobadilla \& Santelices 2005). Dispersal capacity highly depends on the physical oceanographic processes, notably on the water circulation. In this study, we noticed that species with pelagic propagules tend to disperse more on the northern side (compared to the southern side) than do species with benthic propagules. This trend may be due to the general surface water circulation in the Eastern Mediterranean. The general surface circulation of the Mediterranean is strongly influenced by the circulation of the Atlantic current, whose counterclockwise trajectory has been studied since the beginning of the 20th century (Nielsen 1912, Ovchinnikov 1966). This current pattern was sive success of organisms (Lockwood et al. 2005). In our study, we only considered the position of propagules (eggs) in the water column because data on larvae for all Lessepsian fishes included in this study was not available. We were also unable to control for phylogeny in our study because of the lack of molecular data on most of the species. Phylogenetic links between species may disrupt the observed distribution pattern when species are considered as independent while they are not (Ives \& Zhu 2006). Phylogenetic control in correlative studies can be problematic when some genera are over-represented, given that traits are often conserved through lineages. However, most of the 63 Lessepsian species had very

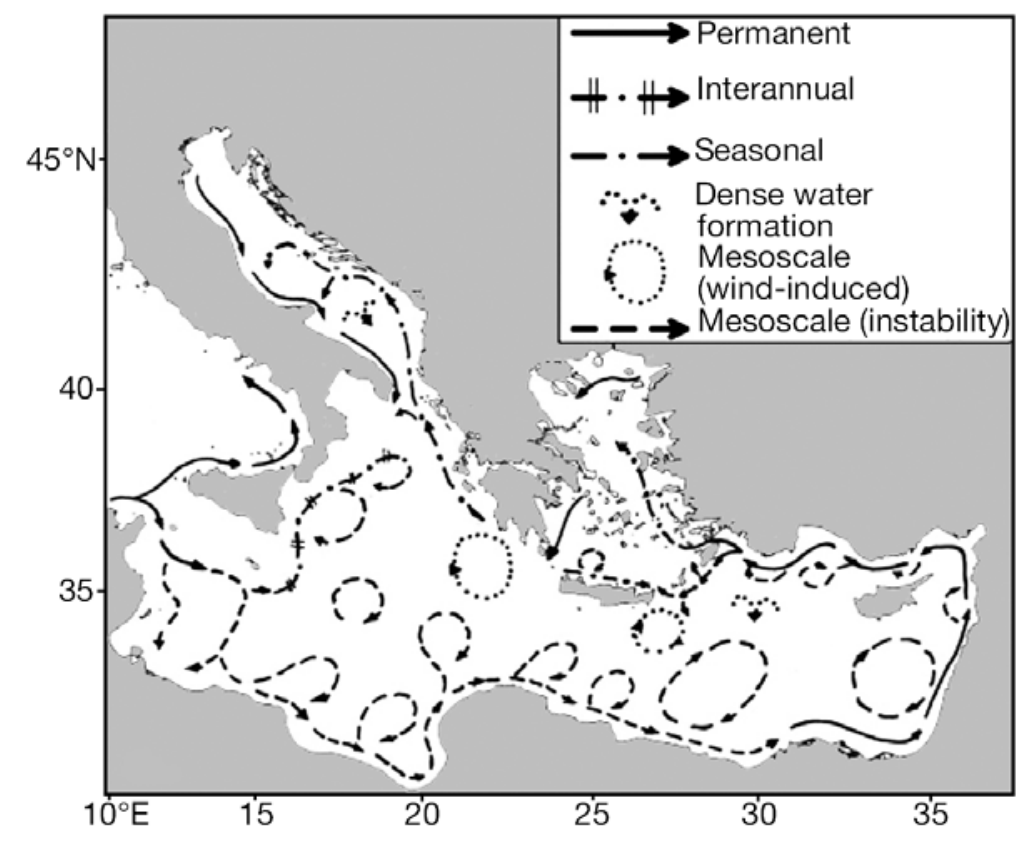

Fig. 7. Atlantic water circulation pattern of the eastern Mediterranean (from Hamad et al. 2005) 
few co-genera and were divided into 45 families, diminishing the potential influence of phylogenetic links in our study.

\section{Red herrings in inventorying Lessepsian fishes}

Some records of Lessepsian species included in our database are somewhat odd. The first record of a species does not necessarily indicate that this species effectively arrived in the Mediterranean Sea at that date: it could have been caught and recorded many years after its first introduction. Moreover, after the reconstruction of dispersal rates, we noticed some unexpected 'jumps'. For instance, Fistularia commersonii (Fig. 8) was identified in the Mediterranean Sea for the first time in 2000 in Israel by Golani (2000). Two years later, it was recorded in Turkey by Gökoglu et al. (2002) and by Bilecenoglu et al. (2002) and around the Greek island of Rhodes by Corsini et al. (2002). In the summer of 2003, it was recorded in the northern Aegean by Karachle et al. (2004). One year later, it was recorded in Tunisia by Ben Souissi et al. (2004) and around the Italian island of Lampedusa by Azzurro et al. (2004), and in 2005 in Sardinia by Pais et al. (2007) (Fig. 8). This species is described as a 'Lessepsian sprinter' by Karachle et al. (2004). Indeed, we found that it progressed at the average speed of $1050 \mathrm{~km} \mathrm{yr}^{-1}\left(\mathrm{SE}=154 \mathrm{~km} \mathrm{yr}^{-1}\right)$ on the northern side. Another species, Upeneus pori, was recorded in Egypt by El Sayed (1994), then in southern Tunisia by Ben Souissi et al. (2005), without any intermediate record. Pomadasys stridens was recorded for the first time in the Gulf of Genoa by Torchio (1969) and then in Egypt by Ben Tuvia (1976).

The distribution of Lessepsian species may also be linked to species transport in ship's ballast waters, which represents an important vector for the introduction of non-indigenous species in marine environments (CIESM 2002, Streftaris et al. 2005). The potential influence of this vector is increasing because of the intense maritime traffic in the Mediterranean Sea (CIESM 2002). The contribution of shipping to the introduction of all alien species (fishes and other groups) into the Mediterranean has been estimated to be about $20 \%$ (Streftaris et al. 2005). However, shipmediated introduction of fish into the Mediterranean Sea is surprisingly rare (Zibrowius 2002, Briggs 2007): among the Lessepsian fishes included in our study, only one record may have been ship-transported via ballast waters: Epinephelus coioides in the Adriatic Sea, recorded by Parenti \& Bressi (2001). Thus, accidental introductions via ship ballast water did not affect our results.

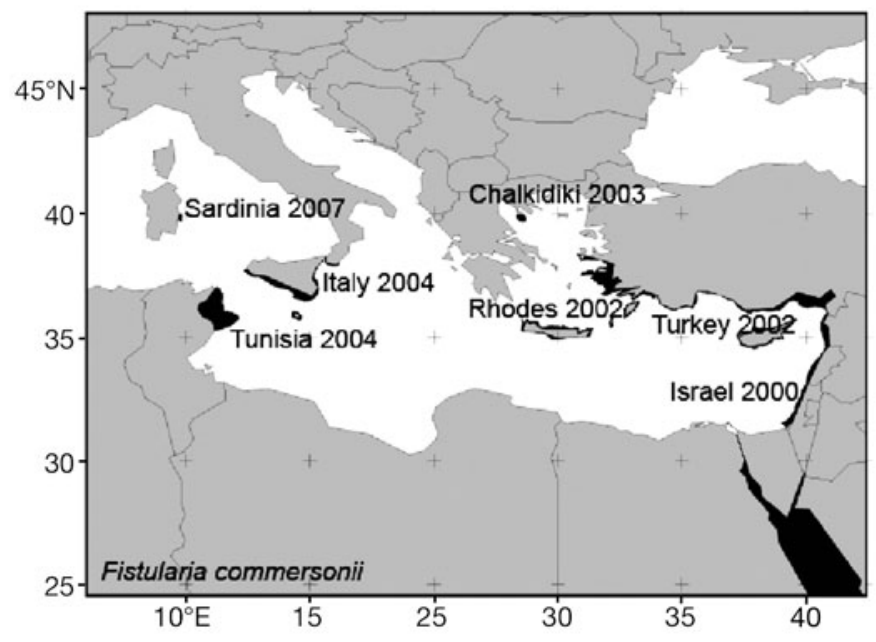

Fig. 8. Fistularia commersonii. An example of fast propagation (black shading)

\section{CONCLUSIONS}

Thirty percent of the Lessepsian species succeeded in dispersing over the Mediterranean Sea. Hence, crossing the Suez Canal does not guarantee the establishment and widespread dispersal of fish populations. Instead, it appears that time since introduction and climate match are key determinants for dispersal, while the type of propagule determines the main pathway of propagation within the Mediterranean. We also found that the transition from the Levantine basin to the western basin is clearly associated with a deceleration in propagation speed. Our study suggests that body size, position in the water column, confamilial resistance and interactions between these factors are all of secondary importance in explaining dispersal success when compared to history, climatic niche and propagule type. Many species accelerated their propagation in the 1980s: on average, the speed increased about 5-fold. This phenomenon could be directly related to the increase in sea surface temperatures observed during the same period. As Lessepsian fishes represent only $5.72 \%$ of the Red Sea fish fauna (Froese \& Pauly 2006), we can expect that the risk of continuing fish invasion from the Red Sea is high, and that the phenomenon may accelerate with further sea surface warming. Similar to other regions, the Mediterranean basin is undergoing a warming trend (Bethoux \& Gentili 1996, Diaz-Almela et al. 2007), and thus Lessepsian fishes that are favoured by warmer temperatures and selected according to their ecological attributes may get established to the detriment of Mediterranean species.

Predicting which Red Sea fishes are most likely to invade the Mediterranean Sea would require thorough knowledge of their ecology. Unfortunately, such data 
are not available, as more than 1000 fishes are present in the Red Sea (Froese \& Pauly 2006). However, our study suggests that basic biological information on fish species may help to predict future invaders. There is wide agreement that, on a global scale, invasive species constitute a major threat to biodiversity (Amborgi 2001, Bax et al. 2001, Perrings 2002, Dawson et al. 2005). However, some authors consider them to be clearly beneficial (Sax et al. 2002, Escapa et al. 2004, Briggs 2007). Regarding the increasing dispersal rate of Lessepsian fish species we can expect some major changes in fish assemblages of the Mediterranean Sea, especially considering global warming (Mandrak 1989, Chu et al. 2005), but the consequences are still challenging to predict.

Acknowledgements. The authors express their gratitude to the Cooperation and Cultural Action Services of the French Embassy in Tunisia that funded this research with a $\mathrm{PhD}$ grant. This project was also supported by the Total Foundation. Authors thank N. Mason for correcting the English, 3 anonymous reviewers who provided very constructive comments on a first draft of the manuscript, and J.B. Ferdy as well as A. Courtiol for helpful discussions on GLMs. K. I. Stergiou (Contributing Editor) and D. K. Moutopoulos greatly improved the manuscript.

\section{LITERATURE CITED}

Ambrogi AO (2001) Transfer of marine organisms: a challenge to the conservation of coastal biocoenoses. Aquat Conserv: Mar Freshwat Ecosyst 11:243-251

Azzurro E, Pizzicori P, Andaloro F (2004) First record of Fistularia commersonii (Fistularidae) from the central Mediterranean. Cybium 28:72-74

Bardin O, Pont D (2002) Environmental factors controlling the spring immigration of two estuarine fishes Atherina boyeri and Pomatoschistus spp. into a Mediterranean lagoon. J Fish Biol 61:560-578

Bax N, Carlton JT, Mathews AA, Haedrich RL and others (2001) The control of biological invasions in the world's oceans. Conserv Biol 15:1234-1246

Ben Eliahu MN, Golani D (1990) Polychaetes (Annelida) in the gut contents of goatfishes (Mullidae), with new polychaete records for the Mediterranean coast of Israel and the Gulf of Elat (Red Sea). PSZNI: Mar Ecol 11:193-205

Ben Souissi J, Zaouali J, Bradai MN, Quignard JP (2004) Lessepsian migrant fishes off the coast of Tunisia. First record of Fistularia commersonii (Osteichthyes, Fistularidae) and Parexocoetus mento (Osteichthyes, Exocoetidae). Vie Milieu 54:247-248

Ben Souissi J, Mejri H, Zaouali J, Capape C (2005) On the occurrence of the Por's goatfish, Upeneus pori (Mullidae) in southern Tunisia (central Mediterranean). Cybium 29: 410-412

Ben Tuvia A (1953) Mediterranean fishes of Israel. Bull Sea Fish Res Stn Isr 8:1-40

Ben Tuvia A (1955) Two Indo-Pacific Fishes, Dasyatis uarnak and Upeneus moluccensis, in the Eastern Mediterranean. Nature 176:1177-1178

Ben Tuvia A, Lourie A (1969) A Red Sea grouper Epinephelus tauvina caught on Mediterranean coast of Israel. Isr J Zool $18: 245-247$
Ben Tuvia A (1976) Occurrence of Red Sea fishes Herklotsichthys punctatus, Autisthes puta and Rhonciscus stridens in the eastern Mediterranean. Isr J Zool 25:212-213

Ben Tuvia A (1977) New records of Red Sea immigrants in the eastern Mediterranean. Cybium 3:95-102

Ben Tuvia A (1978) Immigration of fishes through the Suez Canal. Fish Bull 76:249-255

Ben Tuvia A (1983) An Indo-Pacific Goby Oxyurichthys papuensis in the Eastern Mediterranean. Isr J Zool 32:37-43

Ben Tuvia A (1993) A review of the Indo-West Pacific congrid fishes of genera Rhynchoconger and Bathycongrus with the description of three new species. Isr J Zool 39:349-370

Bertin L (1943) Les clupeiformes du Canal de Suez, comparés à ceux de la Mer Rouge et de la Méditerranée. Bull Mus Natl Hist Nat 15:389-391

$>$ Bethoux JP, Gentili B (1996) The Mediterranean Sea, coastal and deep-sea signatures of climatic and environmental changes. J Mar Syst 7:383-394

Bilecenoglu M, Taskavak E, Kunt KB (2002) Range extension of three Lessepsian migrant fish (Fistularia commersoni, Sphyraena falvicauda, Lagocephalus suezensis) in the Mediterranean Sea. J Mar Biol Assoc UK 82:525-526

> Blackburn TM, Duncan RP (2001) Establishment patterns of exotic birds are constrained by non-random patterns in introduction. J Biogeogr 28:927-939

Bobadilla M, Santelices B (2005) Variations in the dispersal curves of macroalgal propagules from a source. J Exp Mar Biol Ecol 327:47-57

Briggs JC (2007) Marine biogeography and ecology: invasions and introductions. J Biogeogr 34:193-198

> Bruun AF (1935) Parexocoetus, a Red Sea flying fish in the Mediterranean. Nature 136:553

Chu C, Mandrak NE, Minns CK (2005) Potential impacts of climate change on the distributions of several common and rare freshwater fishes in Canada. Divers Distrib 11:299-310

CIESM (2002) Alien marine organisms introduced by ships in the Mediterranean and Black seas. CIESM Workshop Monographs No. 20, Monaco

Collette BB (1970) Rastrelliger kanagurta, another Red Sea immigrant into the Mediterranean Sea, with a key to the Mediterranean species of Scombridae. Bull Sea Fish Res Stn Isr 53:3-6

> Colautti RI, Grigorovich IA, MacIsaac HJ (2006) Propagule pressure: a null model for biological invasions. Biol Invasions 8:1023-1027

- Corsini M, Kondilatos G, Economidis PS (2002) Lessepsian migrant Fistularia commersonii from the Rhodes marine area. J Fish Biol 61:1061-1062

Corsini M, Margies P, Kondilatos G, Economidis PS (2005) Lessepsian migration of fishes to the Aegean Sea: first record of Tylerius spinosissimus (Tetraodontidae) from the Mediterranean, and 6 more fish records from Rhodes. Cybium 29:347-354

Corsini M, Margies P, Kondilatos G, Economidis PS (2006) Three new exotic fish records from the SE Aegean Greek waters. Sci Mar 70:319-323

Crawley MJ (2007) The R book. John Wiley, New York

Darwin C (1859) On the origin of species. John Murray, London

> Davis MA, Grime JP, Thompson K (2000) Fluctuating resources in plant communities: a general theory of invisibility. J Ecol 88:528-534

- Dawson MN, Gupta AS, England MH (2005) Coupled biophysical global ocean model and molecular genetic analyses identify multiple introductions of cryptogenic species. Proc Natl Acad Sci USA 102:11968-11973

> Diaz-Almela E, Marba N, Duarte CM (2007) Consequences of Mediterranean warming events in seagrass (Posidonia 
oceanica) flowering records. Glob Change Biol 13: 224-235

Duncan RP, Bomford M, Forsyth DM, Conibear L (2001) High predictability in introduction outcomes and the geographical range size of introduced Australian birds: a role for climate. J Ecol 70:621-632

El Sayed RS (1994) Check-list of Egyptian Mediterranean fishes. Natl Inst Oceanogr Fish Alexandria

Emlet RB (1995) Developmental mode and species geographic range size in regular sea urchins (Echinodermata: Echinoidea). Evolution 49:476-489

Eryilmaz L, Dalyan C (2006) First record of Apogon queketti Gilchrist (Osteichthyes: Apogonidae) in the Mediterranean Sea. J Fish Biol 69:1251-1254

Escapa M, Isacch JP, Daleo P, Alberti J and others (2004) The distribution and ecological effects of the introduced Pacific oyster Crassostrea gigas (Thunberg, 1793) in northern Patagonia. J Shellfish Res 23:765-772

Filiz H, Er M (2004) Akdeniz'in Yeni Misafiri (New guests in the Mediterranean). Deniz Magazin (Istanbul) 68:52-54

Froese R, Pauly D (2006) FishBase. Accessed June 2006. www.fishbase.org

Gaston KJ (2003) The structure and dynamics of geographic ranges. Oxford University Press, Oxford

George CJ, Athanassiou VA, Boulos I (1964) The fishes of the coastal waters of Lebanon. Miscellaneous papers in the natural sciences. The American University of Beirut 4:1-24

George CJ, Athanassiou V (1967) A two year study of the fishes appearing in the seine fishery of St George Bay, Lebanon. Ann Mus Civ Stor Nat Genova 76:237-294

Gökoglu M, Bodur T, Gulyavuz H (2002) The first record of the bluespotted cornetfish (Fistularia commersonii Ruppell, 1835) (fam: Fistulariidae) along the Turkish Mediterranean coast. Isr J Zool 48:252-254

Gökoglu M, Bodur T, Kaya Y (2003) First record of the Red Sea bannerfish (Heniochus intermedius Steindachner, 1893) from the Mediterranean Sea. Isr J Zool 49:324-325

Golani D (1987) The Red Sea pufferfish, Torquigener flavimaculosus Hardy and Randall 1983, a new Suez Canal migrant to the eastern Mediterranean (Pisces: Tetraodontidae). Senckenb Marit 19:339-343

Golani D (1992) Rhabdosargus haffara (Forsskal, 1775) and Sphyraena flavicauda Ruppell, 1833: new Red Sea immigrants in the Mediterranean. J Fish Biol 40:139-140

Golani D (1993) Trophic adaptation of Red-Sea fishes to the eastern Mediterranean environment: Review and new data. Isr J Zool 39:391-402

Golani D (2000) First record of the bluespotted cornetfish from the Mediterranean Sea. J Fish Biol 56:1545-1547

Golani D (2002) The Indo-Pacific striped eel catfish, Plotosus lineatus (Thunberg, 1787), (Osteichtyes: Siluriformes) a new record from the Mediterranean. Sci Mar 66:321-323

Golani D (2005) Checklist of the Mediterranean fishes of Israel. Zootaxa 947:1-90

Golani D (2006) The Indian scad (Decapterus russelli), (Osteichthyes: Carangidae) a new Indo-Pacific fish invader of the eastern Mediterranean. Sci Mar 70:603-605

Golani D, Ben Tuvia A (1982) First records of the Indo-Pacific daggertooth pike-conger, Muraenesox cinereus, in the eastern Mediterranean and in the Gulf of Eilat (Gulf of Aqaba). Isr J Zool 31:54-57

Golani D, Ben Tuvia A (1986) New records of fishes from the Mediterranean coast of Israel including Red Sea immigrants. Cybium 10:285-291

Golani D, Ben Tuvia A (1990) Two Red Sea flatheads (Platycephalidae) immigrants in the Mediterranean. Cybium 14: $57-61$

Golani D, Fine M (2002) On the occurrence of Hippocampus fuscus in the eastern Mediterranean. J Fish Biol 60:764-766 Golani D, Sonin O (1992) New records of the Red-Sea fishes, Pterois miles (Scorpaenidae) and Pteragogus pelycus (Labridae) from the eastern Mediterranean-Sea. Jpn J Ichthyol 39:167-169

Golani D, Massuti E, Orsi Relini L, Quignard JP (2002) The CIESM Atlas of exotic species in the Mediterranean. Vol 1 Fishes www.ciesm.org/atlas/appendix1.html

Golani D, Sonin O (2006) The Japanese threadfin bream Nemipterus japonicus, a new Indo-Pacific fish in the Mediterranean Sea. J Fish Biol 68:940-943

> Goodwin BJ, McAllister AJ, Fahrig L (1999) Predicting invasiveness of plant species based on biological information. Conserv Biol 13:422-426

Goren M, Dor M (1994) An updated checklist of the fishes of the Red Sea-CLOFRES II. Israel Academy for Sciences abn Humanities, Jerusalem

Goren M, Galil B (1989) Petroscirtes ancylodon, first Lessepsian migrant Blenny in the eastern Mediterranean. Isr J Zool 36:125-128

Goren M, Galil BS (1998) First record of the Indo-Pacific coral reef fish Abudefduf vaigiensis (Quoy \& Gaimard, 1825) in the Levant. Isr J Zool 44:57-59

Goren M, Aronov A (2002) First record of the Indo-Pacific parrot fish Scarus ghobban in the Eastern Mediterranean. Cybium 26:239-240

Goren M, Galil BS (2005) A review of changes in the fish assemblages of Levantine inland and marine ecosystems following the introduction of non-native fishes. J Appl Ichthyology 21:364-370

Haas G, Steinitz H (1947) Erythrean fishes on the Mediterranean coast of Palestine. Nature 160:28

- Hamad N, Millot C, Taupier Letage I (2005) A new hypothesis about the surface circulation in the eastern basin of the Mediterranean Sea. Prog Oceanogr 66:287-298

> Harmelin Vivien ML, Bitar G, Harmelin JG, Monestiez P (2005) The littoral fish community of the Lebanese rocky coast (eastern Mediterranean Sea) with emphasis on Red Sea immigrants. Biol Invasions 7:625-637

Hassan M, Harmelin Vivien M, Bonhomme F (2003) Lessepsian invasion without bottleneck: example of two rabbitfish species (Siganus rivulatus and Siganus luridus). J Exp Mar Biol Ecol 291:219-232

Hengeveld R (1989) Dynamics of biological invasions. Chapman \& Hall, London

Hornell J (1935) Report on the fisheries of Palestine. Government of Palestine. Crown Agent for the Colonies, London

Huntley B (1991) How plants respond to climate change: migration rates, individualism and the consequences for the plant communities. Ann Bot 67:15-22

Ives AR, Zhu J (2006) Statistics for correlated data: phylogenies, space and time. Ecol Appl 16:20-32

Karachle PK, Triantaphyllidis C, Stergiou KI (2004) Bluespotted cornetfish, Fistularia commersonii Rüppell, 1868: a Lessepsian sprinter. Acta Ichtyol Pisc 34:103-108

Kosswig C (1950) Erythräische Fische im Mittelmeer und an der Grenze der Ägais. Syllegomena Biologica Festschrift Kleinschmidt Leipzig p 203-212

Leis JM (1991) The pelagic phase of coral reef fishes: larval biology of coral reef fishes. In: Sale PF (eds) The ecology of fishes on coral reefs. Academic Press, San Diego; CA

Lissner H (1949) Sardine fishing in Israel. Bull Sea Fish Res Stn Isr Scientific Technical Information 2:1-25

Lockwood JL, Cassey P, Blackburn T (2005) The role of propagule pressure in explaining species invasions. Trends Ecol Evol 20:223-228

Lourie A, Bentuvia A (1970) Two Red Sea fishes, Pelates 
quadrilineatus (Bloch) and Crenidens crenidens (Forsskal) in eastern Mediterranean. Isr J Zool 19:203-207

Mandrak NE (1989) Potential invasion of the Great Lakes by fish species associated with climatic warming. J Gt Lakes Res 15:306-316

McArthur RH, Wilson ED (1967) The theory of island biogeography. Princeton University Press, Princeton, NJ

McKinney ML, Lockwood JL (1999) Biotic homogenization: a few winners replacing many losers in the next mass extinction. Trends Ecol Evol 14:450-453

Miller PJ, Fouda MM (1986) Notes on the biology of a Red Sea goby Silhouetta aegyptia (Chabanaud, 1933) (Teleostei: Gobiidae). Cybium 10:395-409

Nielsen JN (1912) Hydrography of the Mediterranean and adjacent waters. Rep Danish Oceanogr Exped 1908-1910 Medit Adj Waters 1:77-192

Mouneimne N (1977) Liste des poissons de la côte du Liban (Méditerranée orientale). Cybium 1:37-66

Mouneimne N (1979) Poissons nouveaux pour les côtes Libanaises. Cybium 6:105-110

Norman JR (1927) Zoological results of the Cambridge Expedition to the Suez Canal. Trans Zool Soc Lond 22: 375-389

Norman JR (1929) Notes on the fishes of the Suez Canal. Proc Zool Soc Lond 2:616

Olden JD, Poff NL, Douglas MR, Douglas ME, Fausch KD (2004) Ecological and evolutionary consequences of biotic homogenization. Trends Ecol Evol 19:18-24

Ovchinnikov IM (1966) Circulation in the surface and intermediate layers of the Mediterranean. Oceanology (Mosc) 6:48-59

Pais A, Merella P, Follesa MC, Garippa G (2007) Westward range expansion of the Lessepsian migrant Fistularia commersonii (Fistulariidae) in the Mediterranean Sea, with notes on its parasites. J Fish Biol 70:269-277

Parenti P, Bressi N (2001) First record of the orange-spotted grouper, Epinephelus coioides (Perciformes: Serranidae) in the northern Adriatic Sea. Cybium 25:281-284

Parin NV (1967) Review of the marine Belonidae of the western Pacific and Indian Ocean. Trudy Inst Okean 84:3-83

Perrings C (2002) Biological invasions in aquatic systems: the economic problem. Bull Mar Sci 70:541-542

Peters RH (1983) The ecological implications of body size. University Press, Cambridge

Quignard JP, Tomasini JA (2000) Mediterranean fish biodiversity. Biol Mar Medit 7:1-66

R Development Core Team (2007) R: a language and environment for statistical computing. The R Project for Statistical Computing, Vienna, Austria. ISBN 3-900051-07-0, URL www.R-project.org

Ruesink JL (2005) Global analysis of factors affecting the outcome of freshwater fish introductions. Conserv Biol 19: 1883-1893

Sanzo L (1930) Plectognathi. Ricerche biologiche su materiali raccolti dal Prof. L. Sanzo nella Campagna Idrografica nel Mar Rosso della J.N. Ammiraglio Magnaghi 1923-1924. Mem R Com Talassogr Ital 167:1-111

Savage VM, Gillooly JF, Brown JH, West GB, Charnov E

Editorial responsibility: Konstantinos Stergiou,

Thessaloniki, Greece
(2004) Effects of body size and temperature on population size. Am Nat 163:429-441

Sax DF, Gaines SD, Brown JH (2002) Species invasions exceed extinctions on islands worldwide: a comparative study of plants and birds. Am Nat 160:766-783

Shanks AL, Grantham BA, Carr MH (2003) Propagule dispersal distance and the size and spacing of marine reserves. Ecol Appl 13:159-169

Silva T, Reino LM, Borralho R (2002) A model for range expansion of an introduced species: the common waxbill Estrilda astrildin Portugal. Divers Distrib 8:319-326

Smith SA, Bell G, Bermingham E (2004) Cross-Cordillera exchange mediated by the Panama Canal increased the species richness of local freshwater fish assemblages. Proc Roy Soc Lond 271:1889-1896

Spanier E, Goren M (1988) An Indo-Pacific Trunkfish Tetrosomus gibbosus (Linnaeus): first record of the family Ostracionidae in the Mediterranean. J Fish Biol 32:797-798

Spanier E (2000) Changes in the ichthyofauna of an artificial reef in the southeastern Mediterranean in one decade. Sci Mar 64:279-284

Spicer IJ (1931) Fisheries. In: Report of the department of agriculture and forests for the years 1927-30. Printing Office, Russian Building, Jerusalem, p 159-160

Steinitz W (1927) Beiträge zur Kenntnis der Küstenfauna Palästinas. PSZNI: Mar Ecol 8:311-353

Strauss SY, Webb CO, Salamin N (2006) Exotic taxa less related to native species are more invasive. Proc Natl Acad Sci USA 103:5841-5845

Streftaris N, Zenetos A, Papathanassiou E (2005) Globalisation in marine ecosystems: the story of non-indigenous marine species across European seas. Oceanogr Mar Biol, Annu Rev 43:419-453

The International Canal Monuments List (1996) Report of the International Committee for the Conservation of the Industrial Heritage www.icomos.org/studies/canals-toc.htm

Tillier JE (1902) Le Canal de Suez et sa faune ichthylogique. Mem Soc Zool Fr 15:279-318

Torchio M (1969) Minacce per l'ittiofauna Mediterranea: le forme esotiche. Atti Soc Ital Sci Nat 109:91-96

Torcu H, Mater S (2000) Lessepsian fishes spreading along the coasts of the Mediterranean and the southern Aegean Sea of Turkey. Turk J Zool 24:139-148

Tortenese E (1984) Mediterranean fishes present in the Red Sea: pan-oceanic and anti-Lessepsian species. Cybium 8: 99-102

Whitehead PJP (1963) A revision of the recent round herrings (Pisces: Dussumieriidae). Bull Br Mus (Nat Hist) Zool 10: 305-380

Wolf CM, Garland T, Griffith B (1998) Predictors of avian and mammalian translocation success: reanalysis with phylogenetically independent contrasts. Biol Conserv 86: 243-255

Zibrowius H (2002) Assessing scale and impact of shiptransported alien fauna in the Mediterranean? In: Alien marine organisms introduced by ships in the Mediterranean and Black seas. CIESM Workshop Monographs 20:63-68

Submitted: May 16, 2007; Accepted: March 5, 2008

Proofs received from author(s): June 30, 2008 